\title{
Defects in High Pressure Die Casting Process
}

Radka Podprocká ${ }^{1}$, Jozef Malik ${ }^{2}$, Dana Bolibruchová ${ }^{3}$

${ }^{1,3}$ Department of Technological Engineering, Faculty of Mechanical Engineering, University of Zilina, Univerzitna 8215/1, 01026 Žilina. Slovak Republic. E-mail: radka.podprocka@fstroj.uniza.sk, danka.bolibruchova@ fstroj.uniza.sk

${ }^{2}$ Metallugry faculty, Department of metallurgy, iron and casting, Košice, Slovak Republic. E-mail: jozef.malik@tuke.sk

Pressure die casting of metals is a method of precise metal casting, where molten liquid metal is forced under high pressure into a mould cavity. Requirements of engineering and automotive industries for perfect castings with smooth surfaces, exact dimensions and thin walls determine the nature and direction of development of pressure die casting of metal. This article analyses the possible causes of a foundry defect - short run - generated during casting based on varying technological parameters.

Keywords: cast, short run, mold, temperature

\section{References}

[1] RAGAN, E. a kolektív. (2007). Liatie kovov pod tlakom, 392s., FVT Prešov, ISBN 978-80-8073-979-9.

[2] VALECKÝ, J. a kolektív. (1963). Lití kovu pod tlakem, 450s., SNTL Praha.

[3] PASTIRČÁK, R. (2014). Effect of low pressure application during solidification on microstructure of AlSi alloys. In: Manufacturing Technology. ISSN 1213-2489. Vol. 14, No. 3 (2014), p. 397-402.

[4] NOVÁ, I., MACHUTA, J. (2013). Squeeze casting results of aluminium alloys. In.: Manufacturing technology. ISSN 1213-2489, Vol. 13, No. 1, pp. 73-79.

[5] NOVÁ, I., NOVÁKOVÁ, I., MACHUTA, J. (2011). Aluminium alloys squeeze casting. In.: Slévárenství. ISSN 1213-2489, Vol. LIX, No. 9-10, p. 304-308.

[6] MICHNA, Š., NOVÁ, I. (2008). Technológia a spracovanie kovových materiálov. Adin, s.r.o. Prešov. ISBN 978 $-80-89244-38-6.336 \mathrm{pp}$.

[7] BOLIBRUCHOVA, D. (2010). Casting technology. GEORG Žilina, ISBN 978-80-89401-14-7, 248 pp.

[8] ŽMINDAK, M. et al., (2014). Finite element analysis of crack growth in pipelines. In: Manufacturing Technology, Vol. 14, No. 1, pp. 116 - 122, ISSN 1213-2489.

[9] MEŠKO, J., ZRAK, A., MULCZYK, K., TOFIL, S. (2014). Microstructure analysis of welded joints after laser welding. In: Manufacturing Technology, Vol. 14, No. 3, pp. 355 - 359, ISSN 1213-2489.

[10]RADEK, N., MEŠKO, J., ZRAK, A. (2014). Technology of laser forming. In: Manufacturing Technology, Vol. 14, No. 3, pp. 428 - 431, ISSN 1213-2489. 